УДК 371.3(378)

Володимир Оліферук, полковник, кандидат технічних наук Національний університет оборони України імені Івана Черняховського, м. Київ

ORCID ID 0000-0002-0722-7561

Дмитро Вітер, доктор філософських наук, старший науковий співробітник Національний університет оборони України імені Івана Черняховського, м. Київ

ORCID ID 0000-0002-7330-1280

Надія Шабатіна,

старший лейтенант,

Національний університет оборони України імені Івана Черняховського, м. Київ

ORCID ID 0000-0002-5066-9517

DOI: $10.33099 / 2617-1775 / 2020-02 / 215-221$

\title{
МОДЕЛЮВАННЯ ПРОЦЕСУ РОЗВИТКУ ВІЙСЬКОВОЇ ОСВІТИ В УКРАЇНІ: ПРИНЦИПИ ТА ПІДХОДИ ДО СТАНДАРТИЗАЦЇ̈
}

Розглянуто методологічні аспекти моделювання процесу розвитку військової освіти в Україні на основі застосування сучасних принщипів та підходів до стандартизацї, що використовуються у краӥнах-членах НАТО. Звернено увагу на необхідність імплементації та широкого застосування ичих принципів та підходів у прочесі вдосконалення системи військової освіти Украӥни. Показано зв'язок концептуальних моделей розвитку військової освіти 3 рамковими документами, які спрямовані на розробку $і$ закріплення кваліфікаційних вимог професійної підготовки офічерів та військових фахівиів.

Ключові слова: галузева рамка кваліфікацій; військова освіта; моделювання; принципи; підходи; професійна військова освіта; стандартизація.

Постановка проблеми. Процес забезпечення реалізації політики професіоналізації військової освіти зорієнтований на інституціоналізацію основаної на результатах системи військової освіти. У цьому аспекті принциповою є трансформація стратегії розвитку військової освіти в межах впровадження основаної на результатах концепції спільного освіти офіцерів, яка являє собою комплекс керівництв вищого рівня, оцінку програмного рівня та звітів з якості підготовки випускників системи спільної військової освіти офіцерів у напрямі досягнення ними визначених результатів проходження навчання в системі професійної військової освіти. Реалізація цього процесу потребує удосконалення підходів до стандартизації військової освіти, що має сприяти розробленню таких програмних документів, як галузева рамка кваліфікацій (далі - ГРК), в яких буде закріплено основні вимоги до професійної підготовки офіцерів та військових фахівців.

Метою статі с аналіз основних принципів та підходів до стандартизації військової освіти в Україні в контексті моделювання процесу ії розвитку. 
Методи дослідження. У статті використано систему загальнонаукових i спеціальних методів теоретичного та емпіричного дослідження (аналіз наукової літератури з досліджуваної проблеми, систематизація та узагальнення, логічнопорівняльний методи, системний підхід, контент-аналіз).

Виклад основного матеріалу. 3 точки зору вирішення завдання щодо формування ГРК доцільно звернутись у процесі стандартизації військової освіти в Україні до принципів цілісності, діагностичності, технологічності, адаптивності, гнучкості, оптимальності, інтегративності, досяжності, ступневості та наступності у межах структурно-ієрархічного підходу, на підгрунті якого відбувається визначення та реалізація основних етапів побудови ГРК. Комплекс теоретикометодологічних принципів та підходів до стандартизації вищої освіти має істотний нормативний потенціал, що забезпечує вирішення завдання щодо практичної реалізації, закріплення i впровадження стандартів вищої освіти в межах національної рамки кваліфікацій та ГРК.

Перевага компетентнісного підходу пов'язана 3 покладеним в його основу принципом орієнтації на кінцевий результат, що найбільш виразно проявляється у сфері професійної освіти, безпосередньо впливаючи на ії цільові установки. Цей підхід орієнтується на два основних методологічних принципи, які застосовуються у процесі стандартизації вищої освіти - цілісність і якість вищої освіти та професійної підготовки фахівців. Фактично має місце концептуалізована на теоретико-методологічному рівні ідея про розвиток системи вищої освіти у напрямі оптимізації кінцевих результатів освітнього процесу, що потребує свого нормативного вираження i закріплення. У результаті стандарт, як цілісна характеристика якості вищої освіти, органічно включається в систему суб'єктоб'єктних відносин освітнього процесу. Крім цього, компетентнісний підхід розглядається як методологічна основа професійної освіти, що забезпечує вимірюваність якості освіти, створення науково обгрунтованих засад для стандартизації та оцінювання результатів освіти. Якщо орієнтуватись на компетентнісний підхід, то варто зазначити, що стандартизація компетентнісно орієнтованої підготовки фахівців безпосередньо пов'язана із завданнями розробки та впровадження у практику НРК, метою якої $є$ наближення та імплементація європейських стандартів і принципів, що регулюють здобуття вищої освіти та створюють умови для подальшого професійного розвитку фахівців.

Методологічно виправданим виявляється застосування принципу outcomebased (як основи розвитку концепції “outcomes-based joint education”) [1], відповідно до якого пріоритетом у визначенні стандартів освіти (перш за все, дескрипторів професійних компетентностей) є орієнтація на кінцевий результат. Однак розуміння результату освітнього процесу в даному випадку відрізняється від результату конкретної практичної діяльності, оскільки вирішення завдань на посаді за призначенням, відображаючись у певному функціоналі, визначає зміст самого процесу підготовки офіцерів та військових фахівців. Відтак, у контексті імплементації стандартних процедур вироблення та прийняття рішень, планування операцій (у тому числі спільних) військ (сил) тощо, прийнятих у збройних силах країн-членів НАТО, зміст підготовки офіцерів та військових 
фахівців 3С України набуває принципово інших ознак, ніж це було раніше [2]. Зокрема, йдеться про можливість розвитку концептуальних положень політики професійної військової освіти, органічно поєднаної зі спільною професійною військовою освітою. Такий підхід забезпечує єдність процесу набуття професійних компетентностей, знань, вмінь та навичок офіцерами і фахівцями сил оборони та сил безпеки, створюючи умови для формування інтегральних компетентностей, необхідних при виконанні службових обов'язків на посадах, що передбачають оперативний та стратегічний рівень прийняття i реалізації управлінських рішень (беручи до уваги стандартизовані процедури планування операцій на рівні об'єднаних штабів, посилення міжвідомчої координації тощо) підчас планування та проведення спільних операцій.

Загальна модель, впроваджувана у країнах-членах НАТО [3],розкриває концепцію загального підходу до розвитку професійної військової освіти на основі рамки“"outcome-based”. Ця модель відтворює ієрархію набуття необхідних компетентностей на різних рівнях освіти, включаючи інституціоналізовані цілі та результати освітнього процесу. Ієрархія результатів, що відображають загальний процес реалізації місії навчання та професійної підготовки, отримують безпосередній зв'язок з оцінюванням якості навчання, забезпечуючи контроль рівня досягненості поставлених цілей навчання і професійної освіти.

Наведена модель орієнтованої на результат рамки професійної військової освіти може бути інтерпретованою в межах прийнятого у вітчизняній системі військової освіти системного підходу, особливостями якого, 3 точки зору реалізації освітньо-педагогічної складової процесу навчання та професійної підготовки офіцерів та військових фахівців та інституційного розвитку системи військової освіти, інтегрованої в загальну національну систему вищої освіти, $\epsilon$ те, що базові принципи, які визначає системний підхід, є сумісними 3 основними елементами запропонованої моделі. Серед таких принципів виділяються: пріоритет кінцевої мети; єдність педагогічної системи, що забезпечує ієрархічну структуру цілей та результатів; динаміка розвитку системи та іï окремих елементів, що підвищує адаптивні можливості суб'єктів та об'єктів процесу навчання з урахуванням змін комплексу індивідуальних і загальних потреб (у тому числі, потреб особистості, потреб ЗС тощо); оптимізація процесу керованості системи на основі адаптивної гнучкості та реагування на вимоги зовнішнього середовища при одночасному збереженні ієрархічності структурної будови системи.

Зважаючи на це, модель “outcomes-based” можна адаптувати й розширити відповідно до потреб розвитку вітчизняної системи військової освіти, що матиме наслідком безпосередню визначеність рамкових умов розвитку професійної військової освіти. Варіант адаптованої моделі показано на рис 1. 
Адаптивна модель розвитку професійної військової освіти на основі принципу “оutcome-based"

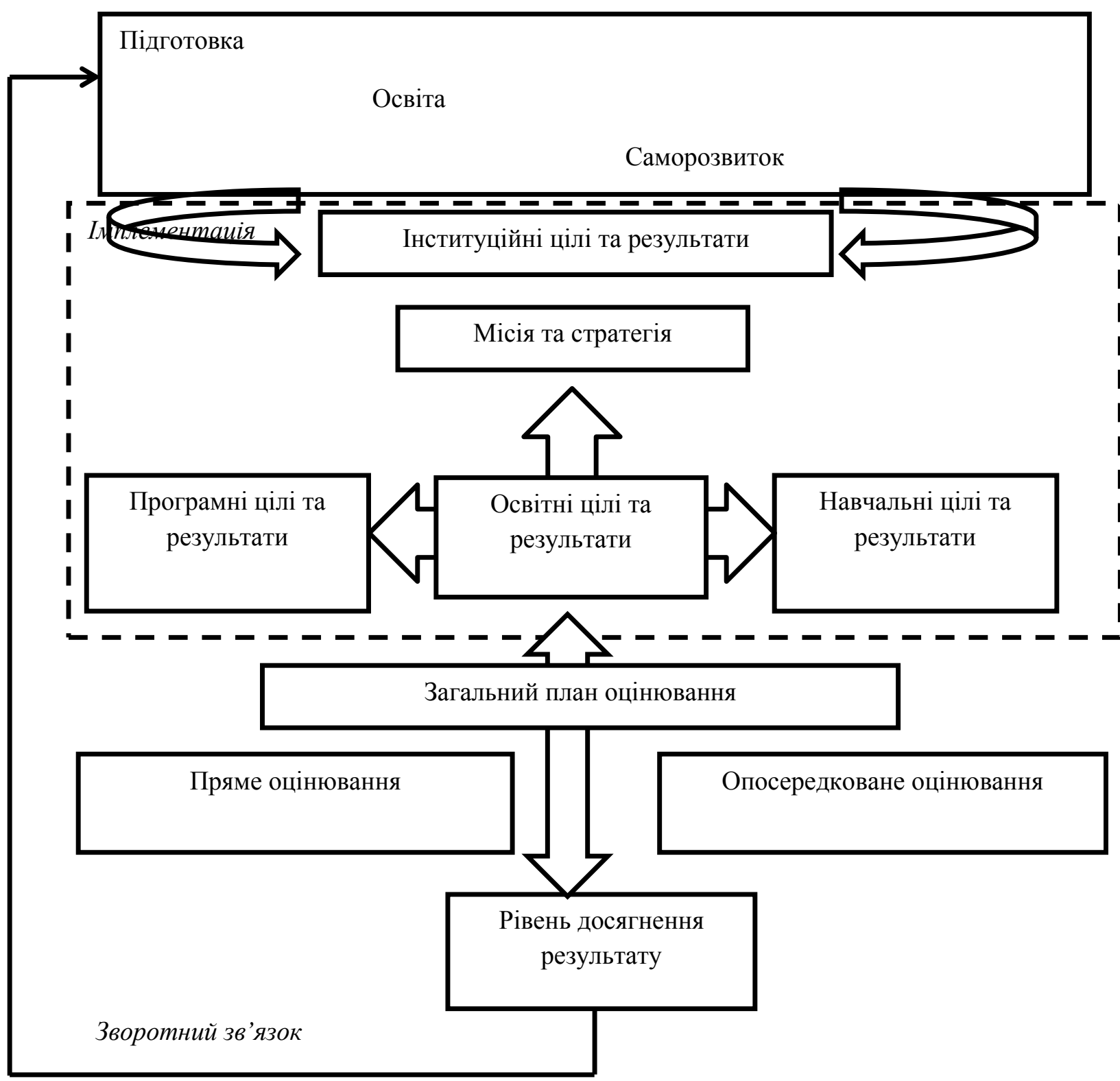

Рис. 1. Адаптивна модель розвитку професійної військової освіти на основі принципу “outcome-based".

Представлена адаптована модель акцентує увагу на важливості інституційнонормативного забезпечення процесу розвитку системи військової освіти, іiі професіоналізації. Для реалізації основних шляхів та заходів, які стосуються інституційно-нормативного забезпечення процесу розвитку військової освіти в Україні, має бути розроблено та імплементовано низку програмних рамкових документів, які відображають сучасний підхід до розвитку системи військової освіти з урахуванням основних тенденцій у цій сфері, наявних в провідних країнах світу, перш за все, країнах-членах НАТО. Фактично йдеться про формалізацію у межах програмного рамкового документу стратегії імплементації концептуальних принципів планування та функціонування системи військової освіти на основі визначених кваліфікаційних вимог, тобто конкретних 
результатів, на які спрямований процес підготовки військових фахівців, та результатів, які очікуються від виконання службових обов'язків на посаді за призначенням.

Подібний програмний рамковий документ спрямований, у першу чергу, на забезпечення професійного розвитку офіцерів та військових фахівців й потребує певної стратегії його імплементації, пов'язаної з ключовими ініціативами та стратегічними цілями, які формуються та обумовлені впливом вимог операційного середовища, створюючи контекст змін, якими потрібно управляти у межах реалізації тих чи інших процедур. Зокрема, існує необхідність узгодження основних процедур планування (вироблення та прийняття рішень тощо) та проведення операцій, які застосовуються у країнах-членах НАТО. Їх перевага полягає в тому, що такі процедури найбільш відображають можливості спільного планування та проведення операцій на тактичному, оперативному і стратегічному рівнях, створюючи умови для раціонального розподілу сил i засобів при забезпеченні координації та взаємодії різних видів і родів військ (сил) збройних сил, інших складових сил безпеки і оборони.

Висновки та перспективи подальших наукових розвідок. Офіцер оперативного і стратегічного рівня має отримати не тільки фундаментальну освіту, але й конкретні компетентності, що обумовлюють його здатність ефективно виконувати завдання на посаді. Відтак, система військової освіти має орієнтуватись на конкретні потреби і завдання функціональної сфери, постійного підвищення рівня професійної підготовки та кваліфікації офіцерів для забезпечення служби на посадах у військах та органах військового управління. Останнє має бути основним критерієм оцінки досягнення результату системою військової освіти, оцінки якості освіти і професійної підготовки офіцерів, а також оцінки ВВНЗ, які мають зосереджувати освітній процес на отримання офіцерами професійних компетентностей у сфері основної професійної діяльності, у сфері функціонального призначення на посаді. Це вимагає застосування нових підходів до формування змісту професійної військової освіти, яка має орієнтуватись та визначатись конкретними завданнями, що вирішуються у військах: планування й проведення спільних операцій (загальновійськових, спеціальних тощо), досягнення високого рівня операційної сумісності, забезпечення міжвідомчої взаємодії та координації планування і проведення операцій на рівні об’єднаних штабів тощо.

\section{ЛІТЕРАТУРА}

1. Вітер Д. Стратегічні пріоритети підвищення боєздатності Збройних Сил України в контексті професіоналізації військової освіти: політики і процедури / Д. Вітер, О. Мітягін // Зб. наук. пр. ЦВСД, 2020, № 1(68), С. 133-137.

2. Hager P. The Integrated View on Competence / Hager P. // M. Mulder (Ed.), Competencebased Vocational and Professional Education. Bridging the Worlds of Work and Education. - Bern: Springer International Publishing, 2017. - P. 203-228.

3. Wolf A. Competence-based assessment / A. Wolf. - Philadelphia: Open University Press, 1995. - $156 \mathrm{p}$. 


\section{REFERENCES}

1. Viter D. Strategichni prioritety pidvischennya boezdatnosti Zbroinyh Syl Ukrainy v konteksti professionalizatsii viyskovoi osvity: politiky i procedury / D. Viter, O. Mityagin // Zb. nauk. pr. CVSD, 2020, № 1(68), S. 133-137.

2. Hager P. The Integrated View on Competence / Hager P. // M. Mulder (Ed.), Competencebased Vocational and Professional Education. Bridging the Worlds of Work and Education. - Bern: Springer International Publishing, 2017. - P. 203-228.

3. Wolf A. Competence-based assessment / A. Wolf. - Philadelphia: Open University Press, 1995. - $156 \mathrm{p}$.

\section{PЕЗЮМЕ}

Владимир Олиферук, полковник, кандидат технических наук Национальный университет обороны Украины имени Ивана Черняховского

Дмитрий Витер, доктор философских наук, старший научный сотрудник

Национальный университет обороны Украины имени Ивана Черняховского

Надежда Шабатина, старший лейтенант Национальный университет обороны Украины имени Ивана Черняховского

\section{Моделирование процесса развития военного образования в Украине: принципы и подходы к стандартизации}

Рассмотрены методологические аспекты моделирования прочесса развития военного образования в Украине на основе использования современных принщипов и подходов $\kappa$ стандартизачии, которые применяются в странах-членах НАТО. Акцентировано внимание на необходимости имплементации и широкого использования этих принципов и подходов в процессе совершенствования системы военного образования Украины. Показана связь концептуальных моделей развития военного образования с рамочными документами, направленными на разработку и закрепление квалификачионных требований профессиональной подготовки офицеров и военных специиалистов.

Ключевые слова: военное образование; моделирование; отраслевая рамка квалификаций; принщипь;; подходы; профессиональное военное образование; стандартизация.

\section{SUMMARY}

Volodymyr Oliferuk, Colonel, $\mathrm{PhD}$ (Technical sciences)

National Defense University of Ukraine named after Ivan Cherniakhovskyi Dmitry Viter, Dr. (Philosophical sciences), senior researcher National Defense University of Ukraine named after Ivan Cherniakhovskyi

Nadiya Shabatina, Senior Lieutenant

National Defense University of Ukraine named after Ivan Cherniakhovskyi 


\section{Modeling the process of the military education in Ukraine development: principles and approaches to the standardization}

Introduction. The process of the military education professionalization politic ensuring, that oriented to military education institutionalization, realization need considering the principles and approaches to military education standardization that directed to program documents (such branch frame of qualifications), in which will determined basic requirements to professional training of the officers and military specialists.

Purpose. Analyze the basic principles and approaches to standardization of the military education in Ukraine in context of it development process modeling.

Methods. The system of general scientific and special methods of theoretical and empirical research (analysis of scientific literature, systematization and generalization of materials, logic and comparative, content analysis) was used in order to realize the article purpose.

Results. The article deals with the methodological aspects of the military education in Ukraine development process modeling on the basic of contemporary principles and approaches to standardization that using in state-members of NATO. There are accented attention to necessity to implementation and active using of those principles and approaches in the process of the Ukraine military education system improvement. The link of conceptual models of the military education development with the frame documents, which is directed to the producing and standing of the officers and military specialists professional training qualification, is demonstrated.

Originality. Adapted model accent attention to importantly of the institutional and normative ensuring the military education system development process, professionalization of it. For realization the main ways and acts that have a link with institutional and normative ensuring the military education system development in Ukraine, must be develop and implement some program framework documents, which demonstrate contemporary approach to military education system development on the statemembers of NATO practice. In fact, is need formalization in frame of program framework document the strategy of the planning conceptual principles and military education system functionality on the base of the determined qualification requirements. In aspect of the military education development modeling take place accent to concrete results, which is goal of the officers and military specialists training process, and results of servicing in army.

Conclusion. The system of military education must orients to concrete needs and tasks in functional sphere, contently of the professional training and officers' qualification level arising for ensuring the service in army and structures of military management. This is basic criteria of the assessment of the military education system results.

Key words: approaches; branch frame of qualifications; modeling; military education; principles; professional military education; standardization. 